\title{
Advertising with Supply Control: Some Implications of Norwegian Whitefish Export Promotion
}

\author{
Gary W. Williams $\oplus^{\bullet}$, and Oral Capps Jr.
}

\begin{abstract}
An issue for generic advertising in agricultural markets with unregulated supplies is that the promotion-induced demand shift could lead to a supply response that substantially attenuates the price effects of the promotion. For the generic promotion of fish exports, however, the concern is generally just the oppositethe possibility that extensive government supply controls could render promotion efforts to expand export sales ineffectual due to little or no supply response. This study considers the effects of government whitefish (cod, haddock, and others) supply controls on the effectiveness of the Norwegian Seafood Council (NSC) whitefish export promotion program. We use an econometric simulation model to measure the effectiveness and returns to NSC whitefish export promotion under a range of possible export supply control conditions. Results indicate that effective supply control maximizes the return to promotion and that ineffectual supply control imposes a potentially large opportunity cost on the promoting industry.
\end{abstract}

Key words: Norway, whitefish exports, supply control, advertising and promotion, benefit-cost analysis, econometric simulation

JEL Codes: Q22, Q27, Q21, Q28

Because most fisheries are regulated, research has generally concluded that fish supplies are largely determined by the size of their respective fishery quotas (e.g., Arnason 2004, Asche and Hannesson 2002, Pascoe and Mardle 1999, Rudders and Ward 2015). Despite supply controls, however, the Norwegian Seafood Council (NSC), a public company owned by the Norwegian Ministry of Trade, Industry and Fisheries, has worked to promote the demand for a wide variety of Norwegian seafood in markets all over the world. The importance of supply response to advertising was first discussed in a nowclassic article by Nerlove and Waugh (1961). Subsequent research has been most concerned with the possibility that a supply response in markets without supply controls could substantially lessen or even completely offset

Gary W. Williams, Professor and Co-Director of the Agribusiness, Food and Consumer Economics Research Center, Texas A\&M University, Department of Agricultural Economics, College Station, Texas. Oral Capps, Jr., Executive Professor and Regents Professor, Co-Director of the Agribusiness, Food and Consumer Economics Research Center, Texas A\&M University, Department of Agricultural Economics, College Station, Texas. Correspondence: Gary W. Williams, 600 John Kimbrough Blvd, Suite 371, College Station, TX 77843-2124.Email: gwwilliams@tamu.edu

Agricultural and Resource Economics Review 49/3 (December 2020) 558-585

(C) The Author(s) 2019. This is an Open Access article, distributed under the terms of the Creative

Commons Attribution licence (http://creativecommons.org/licenses/by/4.0/), which permits unrestricted re-use, distribution, and reproduction in any medium, provided the original work is 
the long-term price effects of demand promotion ${ }^{1}$ (for example, Carman and Green 1993, Kinnucan, Nelson, and Xiao 1995, Williams, Shumway, and Love 2002). For the promotion of fish exports, however, the concern is generally just the opposite-the possibility that extensive supply controls could render promotion efforts to expand export sales ineffectual due to no or limited supply response.

Whitefish is one of the main categories of fish exports promoted by the NSC. Salmon and pelagics (primarily mackerel and herring) are the other two main categories of fish exports promoted by the NSC. The whitefish category encompasses several highly diverse fish species around the world relative to production technology (capture fisheries vs. aquaculture) and habitat (marine vs. freshwater), including cod, skrei, saithe, whiting, haddock, pollock, and others. Norwegian whitefish exports are primarily wild caught rather than farmed like Norwegian salmon. Atlantic cod is the highest-priced Norwegian whitefish species and is either the largest or the second-largest species by export volume. Saithe alternates with cod as the largest Norwegian whitefish export by volume. Haddock is generally regarded as more important than saithe, however, because of its higher price. Like most Norwegian fisheries, the Norwegian whitefish catch is managed by annual Total Allowable Catch (TAC) limits in agreement with other countries, based on recommendations by the International Council on Exploration of the Seas (ICES). TACs are decided in December so that fishing can commence in the new calendar year.

Given the aggressive promotional efforts of the NSC in the face of supply controls, this study considers the effectiveness of NSC whitefish export demand promotion and the implications for the Norwegian whitefish industry that funds the promotion. After some background on Norwegian whitefish exports and NSC whitefish export promotion programs, a review of past studies related to Norwegian whitefish exports is provided. The methodology used in this study to measure the effectiveness of NSC whitefish export promotion under alternative export supply control conditions is then followed by a discussion of the analytical results. Finally, the major conclusions and implications of the study are addressed.

\section{Norwegian Whitefish Exports and Promotion}

The volume and value of Norwegian whitefish exports both experienced substantial growth between 2003 and 2017 (Figure 1). Norwegian whitefish export value grew at a faster annual average rate of 5.6 percent over that period, however, compared to 3.1 percent for the export volume. As a result, the export value doubled over that period from NOK (Norwegian Kroners) 7.3 billion (\$US 1.0 billion) to NOK 15.0 billion (\$US 2.6 billion), while the

\footnotetext{
1 The term "promotion" is used in this article to refer to all traditional media advertising and non-media demand promotion programs and expenditures.
} 


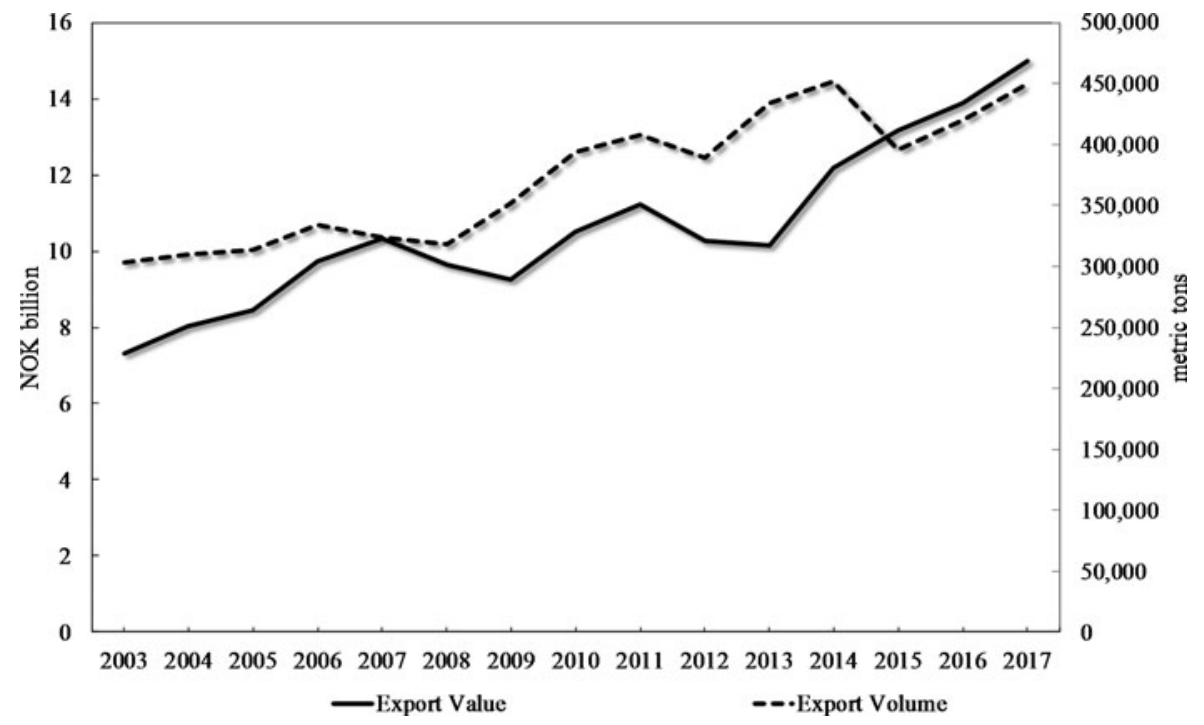

Figure 1. Norwegian annual whitefish export value and volume, 2003-2017 Source: NSC (2018).

export volume posted only about a 50 percent increase from 303,091 metric tons (mt) to $449,899 \mathrm{mt}$. The jump in the export value was facilitated by a 38 percent increase in the average annual price of Norwegian whitefish exports over that period, from $24.2 \mathrm{NOK} / \mathrm{kg}$ (\$US $1.55 / \mathrm{lb}$ ) to $33.3 \mathrm{NOK} / \mathrm{kg}$ (\$US $1.82 / \mathrm{lb})$.

Norway exported whitefish to nearly 160 different countries between 2003 and 2017 (NSC 2018). ${ }^{2}$ The top 10 importing countries accounted for 71.1 percent of those exports, including China (14.4 percent), Denmark (12.6 percent), Portugal (11.8 percent), the UK (9.1 percent), Brazil (7.0 percent), France ( 4.3 percent), the Netherlands (3.4 percent), Poland (3.3 percent), Spain (2.7 percent), and the United States (2.5 percent). Norwegian whitefish exports exhibited a definite pattern of monthly seasonality over 2003 to 2017 with highs in the months of September through November and January through March and lows in December and the summer months of May through August. Consequently, the monthly price of whitefish exports also has exhibited strong seasonality.

Fresh and frozen whitefish (not salted, dried, or otherwise further processed) have dominated Norwegian whitefish exports, accounting for about 60 percent to 70 percent of the total over 2003 to 2017. Clipfish (klippfisk) and other salted

\footnotetext{
2 More information on Norwegian landings of fish and the management system can be found, for example, in Guttormsen and Roll (2011) and Cojocaru et al. (2019).
} 


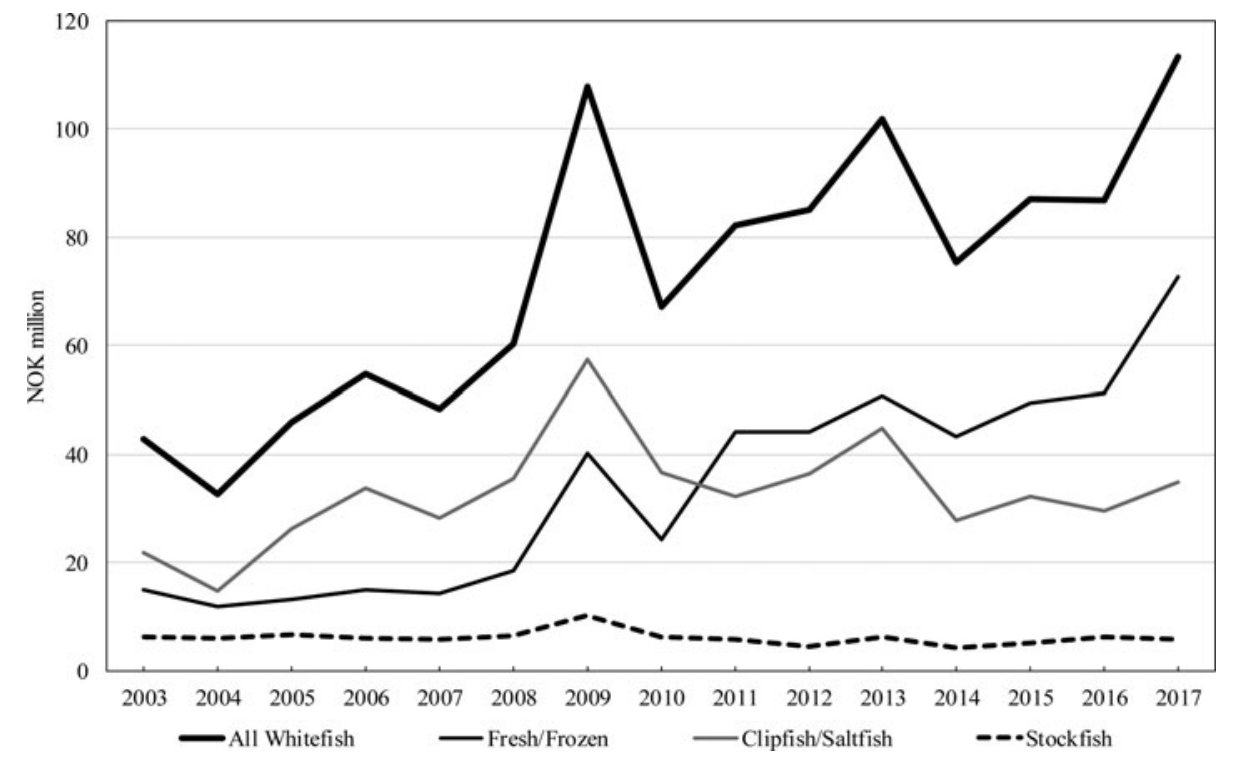

Figure 2. Annual nominal NSC whitefish export promotion expenditures by type, 2003-2017

Source: NSC (2018).

whitefish (saltfisk), salted and dried forms of Norwegian whitefish, accounted for up to nearly 40 percent of exports over that period but only about 25 percent in 2017. Stockfish (tørrfisk), whitefish dried on open-air timber racks or "stocks," have accounted for an average of only about 2 percent of Norwegian whitefish exports.

In recent years, traditional Norwegian whitefish markets have become more global, with the introduction of Alaskan pollock, hoki, South Atlantic hake, and others (Hellandsjø 2015). At the same time, new tropical and subtropical whitefish have joined catfish and other freshwater species in the global whitefish market with tilapia and pangasius as the two most important (Asche, Roll, and Trollvik 2009). In addition, Norway continues to compete with whitefish exports from other countries such as Iceland, Greenland, Russia, China, and the United States.

Among the Norwegian whitefish species, the NSC has primarily targeted cod for promotion, but also haddock and even saithe at times. A levy on the value of all whitefish exports which funds the promotion increased from 0.30 percent in 2003 through 2009 to 0.50 percent in 2010 and then to 0.75 percent through 2017. NSC whitefish promotion expenditures trended upward between 2003 and 2017, hitting a record NOK 113.4 million (\$US 13.5 million) in 2017 (Figure 2), about 24 percent of the total NSC seafood promotion budget. Between 2003 and 2009, clipfish/saltfish dominated NSC whitefish export promotion, accounting for 50 percent to 60 percent of those expenditures, 
but then began a slow decline to NOK 34.8 million (\$US 4.1 million) by 2017, about 31 percent of whitefish expenditures. In contrast, fresh and frozen whitefish promotion expenditures increased substantially from NOK 14.8 million (\$US 1.8 million) in 2003 to a high of NOK 72.7 million (\$US 8.7 million) in 2017, reaching 64 percent of whitefish promotion expenditures. The stockfish share of promotion expenditures declined over that period from 14.5 percent of total whitefish expenditures in 2003 to just 5.1 percent in 2017.

Despite the upward trend in the nominal NOK value of NSC whitefish promotion expenditures over that period, price inflation in major foreign markets for Norwegian whitefish and a general depreciation in the NOK against the currencies in those countries eroded the real purchasing power of those expenditures over the January 2003 to December 2017 period. NSC whitefish promotion expenditures exhibited a definite seasonality pattern over the same period distinct from that of whitefish exports. Over those years, expenditures demonstrated an increasing tendency to concentrate into the first few months of each year (January through April), although month-tomonth spurts in spending have been common during other times of the year.

\section{Previous Research}

A broad body of literature reports econometrically estimated demand parameters for a broad species of whitefish. Little has been done, however, on the supply of whitefish and even less on the NSC export promotion of whitefish. On the demand side, the literature concludes that the demand for whitefish is generally inelastic but varies widely by specific whitefish species, including cod (from -0.21 by Asche and Zhang [2013] to -2.40 by Xie and Myrland [2010]), haddock (from -0.11 by Asche and Zhang [2013] to -0.69 by Fousekis and Revell [2004]), and saithe (from - 0.39 by Hellandsjø [2015] to -1.10 by Bronnmann [2016]). Income elasticities across those same studies vary from relatively low (about 0.5 ) to relatively high (about 2.0).

The sparse literature on whitefish supply generally concludes that the supply of these capture species is largely determined by the quotas set and not so much by price (for example, Arnason 2004, Pascoe and Mardle 1999). In contrast, aquaculture species like salmon can respond to increasing prices with larger supply (Andersen, Roll, and Tveterås 2008). Norwegian salmon production regulations tend to focus on managing growth based on biological sustainability rather than limiting its expansion, as has been the case with whitefish and most other fisheries (Hersoug 2015, Besson et al. 2017).

Little is known about the effectiveness of Norwegian whitefish export promotion. NSC salmon export promotion, however, has been studied extensively (Myrland and Kinnucan 2000, Kinnucan and Myrland 2000, 2001, 2002, 2003, 2006, Xie, Kinnucan, and Myrland 2009, Xie 2008 and 2015, and Kaiser 2015). These studies report a wide range of both salmon promotion elasticities (0.01 to 0.054$)$ and promotion benefit-cost ratios (BCRs) (-0.08 to 
9.53) based on divergent assumptions regarding the Norwegian salmon export supply elasticity (Williams and Capps 2017). A recent study concludes that NSC promotion across all seafood exports added about 10 percent to the aggregate export value of Norwegian seafood between 2003 and 2016, resulting primarily from an export price increase of up to 12 percent and an export volume increase of up to 6.5 percent, depending on the price elasticity of the Norwegian seafood export supply (Williams and Capps 2017). The study reports a likely promotion BCR range of 4.2 to 15.7 kroner per krone spent on promotion. Only one study has examined NSC promotion of whitefish exports reporting an average BCR for skrei and fresh cod of 1.02 and 4.56, respectively, over 2003 to 2015 (CAPIA AS 2016).

\section{Methodology and Data}

To investigate the effectiveness of Norwegian whitefish promotion under various scenarios regarding the restrictiveness of the export supply controls, we postulate a simple three-equation conceptual model for Norwegian whitefish exports:

$$
\begin{aligned}
& \mathrm{NWXD}_{\mathrm{t}}=\mathrm{NWXD}\left(\mathrm{NWPX}_{\mathrm{t}}, \mathrm{G}_{\mathrm{t}}, \mathrm{ZD}_{\mathrm{t}}\right) \\
& \operatorname{NWXS}_{\mathrm{t}}=\operatorname{NWXS}\left(\mathrm{NWPX}_{\mathrm{t}} /(1+\theta)_{\mathrm{t}}, \mathrm{ZS}_{\mathrm{t}}\right) \\
& \mathrm{NWXS}_{\mathrm{t}}=\mathrm{NWXD}_{\mathrm{t}}
\end{aligned}
$$

where NWXD is the foreign demand for Norwegian whitefish exports aggregated over all destinations; NWXS is the export supply of Norwegian whitefish, NWPX is the average price paid for Norwegian whitefish exports; $\theta$ is the ad valorem promotion levy assessed by NSC on whitefish exports; $\mathrm{NWPX}_{\mathrm{t}} /(1+\theta)_{\mathrm{t}}$ is the price received by Norwegian whitefish exporters for whitefish exports (=NWP); G is the "goodwill" or stock variable representing export promotion expenditures (Nerlove and Arrow 1962); ZD is a matrix of all other demand shift variables, including income (GDP) measures for importing countries, exchange rates relative to the NOK for those countries, competing freshwater (aquaculture) fish export prices, inflation, and numerous qualitative events that have impacted Norwegian whitefish exports over the period of 2003 through 2017; and ZS is an equivalent matrix of supply shift variables.

After discussing the econometric estimation of equation (1), the export supply response to price in equation (2) is considered. The counter-factual (simulation) process using the model to measure the price and export response to NSC whitefish export promotion under alternative supply control conditions is then discussed followed by an explanation of the procedure used to determine the Norwegian whitefish industry returns from promotion. 


\section{Norwegian Whitefish Export Demand Equation}

The specification of equation (1) for the Norwegian whitefish export demand benefitted from the work of Kaiser (2015), Williams et al. (2016), and many of the export promotion studies they review. The dependent variable in equation (1) is the monthly demand for Norwegian whitefish exports (NWXD). The monthly price variable (NWPX) is the export unit value of Norwegian whitefish exports expressed in NOK per kilogram (kg). To account for changes in currency values against the NOK, NWPX was multiplied by a monthly trade-weighted exchange rate index (base period 2010) across the top ten importing countries in each month of each year. The trade weights are the monthly shares of Norwegian whitefish exports accounted for by the top ten importing countries from 2003 to 2017. The trade-weighted NOK exchange rate was developed using monthly trade weights calculated from monthly Norwegian whitefish export data (NSC 2018) and exchange rate data (IMF 2018). The exchange-rate-adjusted whitefish export price was then deflated by the FAO aquaculture fish price index (FAO 2018, Tveterås 2018, Tveterås et al. 2012) to account for the price pressure on Norwegian whitefish exports from growing global export supplies of aquaculture fish species.

To represent the purchasing power of consumers in importing countries in equation (1), the Gross Domestic Products (GDPs) of the top ten importing countries were converted to NOK, multiplied by their trade weights, deflated by an aggregate trade-weighted Consumer Price Index (base period 2010) for the same countries, and aggregated into a single real GDP measure for each month in each year (2010 NOK). The real aggregate GDP measure was then multiplied by the monthly trade-weighted exchange rate index to account for changes in currency values against the NOK.

We also tested for the significance of the Norwegian salmon price as a driver of whitefish export demand following Fousekis and Revell (2004) and Singh, Dey, and Surathkal (2012 and 2014) among others. Like the whitefish export price, the Norwegian salmon export price was exchange-rate adjusted and deflated by the FAO aquaculture price index.

The goodwill variable G in equation (1) is a transformation of NSC whitefish export promotion expenditures to account for several key characteristics of the relationship between those expenditures and whitefish exports. First, NSC whitefish promotion expenditures were seasonally adjusted using the X13 technique (using EVIEWS 9.5 2018) to avoid confounding associated with seasonality. Second, the expenditures were exchange-rate-adjusted as done for the whitefish export price (NWPX) and inflation-adjusted using the tradeweighted Consumer Price Index (base 2010) in importing countries.

Third, a large body of literature supports the hypothesis that promotion expenditures have carryover or lagged effects (e.g., Nerlove and Waugh 1961, Lee and Brown 1986, Ward and Dixon 1989, Williams, Shumway, and Love 2002, Ghosh and Williams 2016, Williams and Capps 2017, Williams and Capps 2018, among many others). Economic theory provides relatively little 
guidance as to the structure and length of this dynamic process, however. We follow a common practice in the literature of using the Almon polynomial distributed lag (PDL) formulation to account for the time lag in the impact of the NSC export promotion expenditures on Norwegian whitefish export demand.

The search for the pattern, polynomial degree, and period over which the promotion expenditures influence Norwegian whitefish export demand involved a series of nested OLS regressions. Conventionally, researchers use statistical criteria like the Akaike Information Criterion (AIC), the Schwarz Loss Criterion (SLC), or the Hannan-Quinn Criterion (HQC) to allow the data to suggest the optimal number of lags to include in the specification. Previous research on a broad range of food products suggests that the full impacts of promotion expenditures in a given month occur within no more than a year following the expenditure. Hence, we considered lags of NSC expenditures up to twelve months. The econometric results indicate the short-run and longrun or cumulative effects as well as the average length of time (in months) before changes in NSC export promotion expenditures begin affecting the Norwegian whitefish export demand.

Finally, NSC expenditures in equation (1) were transformed to capture the effects of diminishing marginal returns associated with advertising wearout (Kinnucan, Chang, and Venkateswaran 1993). To capture those effects, we implemented a logarithmic transformation of the exchange rate-adjusted, deflated, and seasonally adjusted NSC export promotion expenditures as is commonly done (Williams et al. 2016).

While economic variables like purchasing power in importing countries, the export prices of whitefish, salmon, and other competing species, exchange rates, and promotion expenditures explain the long-term trends in exports, various events in global whitefish markets may have impacts in specific years or across many years. For example, the seasonal patterns evident in the volume of monthly Norwegian whitefish exports must be accounted for in the analysis. In addition, various qualitative events may affect global markets for whitefish in particular years and must be taken into account to isolate more accurately the effects of promotion on exports. The major global events with potential to impact Norwegian whitefish exports were identified in discussion with NSC personnel and treated as indicator variables in equation (1). Finally, we consider habit persistence or inertia using a one-period lag in the volume of whitefish exports.

\section{Norwegian Whitefish Export Supply Price Response}

Equation (2) of the model defines the response of Norwegian whitefish export supplies to changes in price. The critical link between supply response and the effectiveness of export promotion is illustrated in Figure 3. Assume, for example, that the promotion of the foreign demand for Norwegian whitefish shifts out the demand for whitefish exports in a given year from NWXDwo to NWXDw, as depicted in Figure 3 (where "wo" and "w" mean 


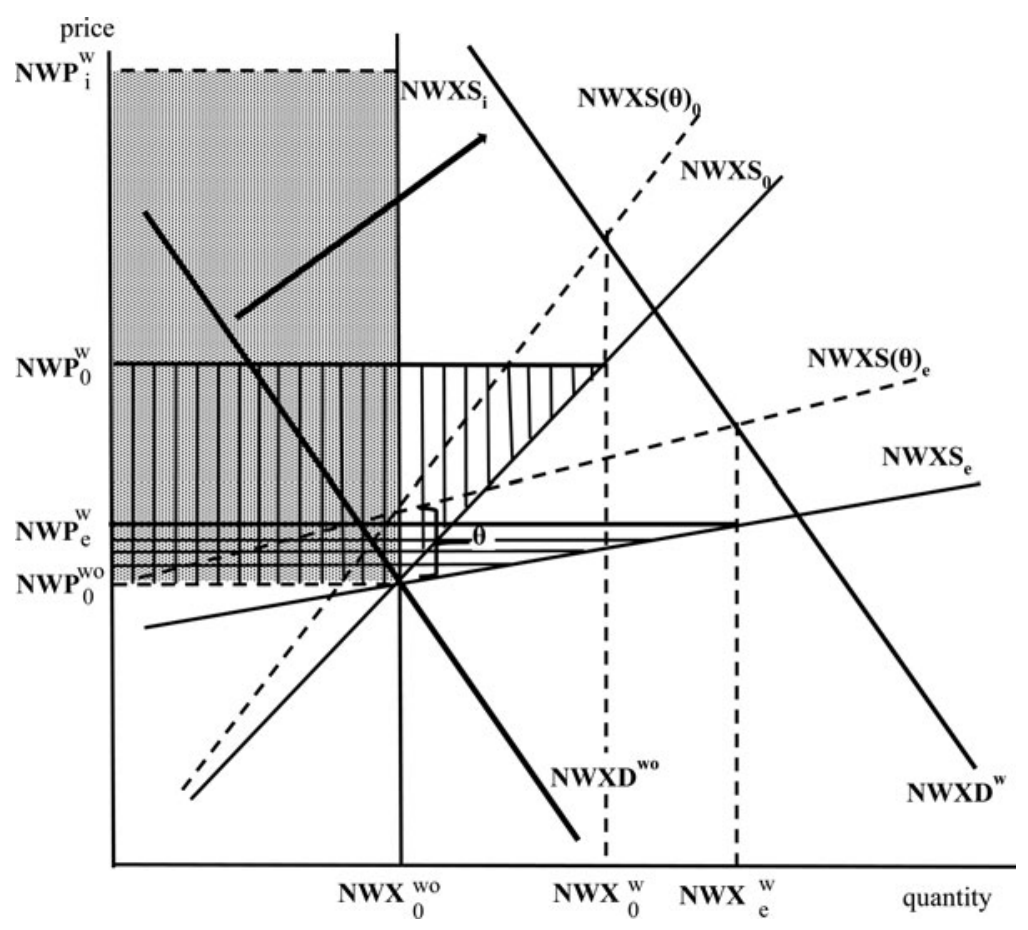

Figure 3. Market and welfare effects of Norwegian whitefish export demand promotion

"without" and "with" promotion, respectively). Consistent with Chang and Kinnucan (1991), the ad valorem levy on Norwegian whitefish exports behaves like an excise tax, the cost of which is shared by producers and consumers. Graphically, the effect of the levy is manifest with two export supply curves separated vertically by the ad valorem promotion levy $(\theta)$. The higher of the two curves represents the prices paid by foreign consumers at various levels of Norwegian whitefish exports (NWPX). For clarity of exposition and because our focus is the effects of promotion on Norway, only the prices received by exporters (NWP) given the levy are shown in Figure 3.

Given little or no export supply control as reflected in an elastic export supply like $\mathrm{NWXS}_{\mathrm{e}}$ in Figure 3, most of the adjustment to a successful promotion program is manifest as an increase in export volume $\left(\mathrm{NWX}_{0}^{\mathrm{wo}}\right.$ to $\left.\mathrm{NWX}_{\mathrm{e}}^{\mathrm{w}}\right)$ rather than an increase in export price $\left(\mathrm{NWP}_{0}^{\mathrm{Wo}}\right.$ to $\left.\mathrm{NWP}_{\mathrm{e}}^{\mathrm{W}}\right) \cdot{ }^{3}$ Even though the

\footnotetext{
3 The price received by Norwegian exporters for their whitefish exports (NWP) is the "export" price here.
} 
export price increase from the promotion-induced export demand shift is moderated by the vigorous export supply response in this case, export sales revenue is higher because the export quantity sold at the somewhat higher export price increases. The total cost of exporting also increases with the higher exports, however, so that the net benefit to the industry in terms of an increase in export surplus ${ }^{4}$ (the horizontally lined area in Figure 3) is smaller than the net export revenue increase from the tax. The industry net benefit is positive unless the export supply is perfectly price elastic.

A less price-elastic export supply such as $\mathrm{NWXS}_{0}$ in Figure 3, representing, perhaps, some effectiveness of supply controls, would result in a higher increase in the export price $\left(\mathrm{NWP}_{0}^{\mathrm{wo}}\right.$ to $\mathrm{NWP}_{0}^{\mathrm{W}}$ ) and a smaller increase in export sales ( $\mathrm{NWX}_{0}^{\mathrm{wo}}$ to $\mathrm{NWX}_{0}^{\mathrm{W}}$ ) than occurs with no (or ineffective) export controls. The resulting increase in the net benefit to the industry (the vertically lined area in Figure 3) is larger as a result.

Given absolute control of whitefish export supplies represented by a perfectly inelastic export supply $\left(\mathrm{NWXS}_{\mathrm{i}}\right)$, the adjustment to a successful promotion program is manifest solely as an increase in the export price $\left(\mathrm{NWP}_{0}^{\mathrm{wo}}\right.$ to $\left.\mathrm{NWP}_{\mathrm{i}}^{\mathrm{W}}\right)$, leading to additional industry export revenue represented by the shaded rectangle in Figure 3. Thus, even if the export price increases considerably from the promotion, foreign sales cannot increase beyond $\mathrm{NWX}_{0}^{\mathrm{wo}}$ due to the supply restriction. Because export demand promotion has no effect on export volume, export suppliers' costs of exporting do not change. Consequently, the increase in export revenue from the promotion is the addition to export surplus and the net benefit to the Norwegian whitefish industry.

Despite the generally accepted conclusion that fish supplies are exogenously determined, some level of long-run price responsiveness of the Norwegian whitefish export supply seems reasonable for various reasons. First, pushed by high prices and profits, overfishing established quotas has been a problem over the years (Gullestad et al. 2014). Improved fishery management systems have reduced the incidence of overfishing, but overall compliance with the UN Code of Conduct for Responsible Fisheries (FAO 1995), which focuses on the prevention of overfishing, is less than perfect. Pitcher et al. (2009) rated Norway's fishery system the highest on compliance with the code at only about 60 percent.

Second, the Norwegian whitefish catch has been below the TAC in some years over the study period (HAVFISK 2015). During such periods, price likely plays

\footnotetext{
4 The "export surplus" is the difference between the gain in producer surplus and the loss in consumer surplus in Norway from a rise in price resulting from the increase in foreign demand for Norwegian whitefish. Thus, the "export surplus" is the net gain to the Norwegian economy from the promotion of Norwegian whitefish exports. Because the domestic market accounts for only about 5 percent of the Norwegian whitefish catch, the "export surplus" in this case approximates Norwegian whitefish producer surplus. Thus, in this article, we use "export surplus" as the measure of producer surplus. For this reason, an increase in "export surplus" is deemed the net benefit to the Norwegian whitefish industry.
} 
at least some role in the corresponding supply changes. The demand-enhancing efforts of NSC during those periods helped push production towards the TAC limits by enhancing export demand and, thus, price.

Third, the export supply of whitefish is not the same thing as the domestic production of whitefish. Export supply curves are normally more elastic than their domestic counterparts because they are the difference between the domestic supply and demand curves. Although Norway exports about 95 percent of its whitefish supply (NSC 2018), the export supply can increase to some extent as the export price increases by drawing down the supply available to the small domestic market.

Finally, the quota levels themselves may be somewhat responsive to price trends over time. For example, after a period of increasing cod quotas and declining prices from 2009 through 2013, whitefish quotas were then reduced several years in a row with dramatic price supporting effects. Between 2013 and 2016, the export price of Norwegian frozen whole cod jumped by over 80 percent (Statista 2018). Then for 2017, with continuing high cod prices, Norway and Russia agreed on a total cod TAC of 890,000 mt, more than 11 percent above the ICES recommendation of 805,000 $\mathrm{mt}$, leaving the TAC total little changed from the previous year. Then for 2018 when the ICES recommended a 20 percent cut in the cod TAC, Norway and Russia agreed on only a 13 percent cut to $775,000 \mathrm{mt}$. The higher negotiated levels of the TAC over the ICES recommendations in each year may reflect the higher prices for cod in export markets to some degree.

Studies using data before Norwegian fishery quota systems were fully binding found that the price elasticity of Norwegian fish supplies ranged from inelastic (Salvanes and Squires 1995) to unitary elastic (Asche 2009). In more recent modeling of world fish supply by the World Bank, capture fish supplies are assumed to be completely price inelastic (Msangi et al. 2013). They assume the supply elasticity of aquaculture species, however, to be somewhere between 0.5 and 1.0. So over both capture and aquaculture, the supply of fish in the World Bank model would be somewhere between zero and 1.0. Asheim et al. (2011) reported a low price elasticity of Norwegian salmon supply in both the short run (0.091) and long run (0.141). Steen, Asche, and Salvanes (1997), Asche, Kumbhakar, and Tveterås (2007) and Andersen, Roll, and Tveterås (2008), however, reported higher Norwegian salmon supply elasticities of about 1.4 to 1.5. The export supply elasticities estimated or assumed by studies of the NSC salmon promotion program have ranged from close to zero to 2.0 (Williams and Capps 2017).

Allowing that the Norwegian whitefish export supply is not likely to be perfectly inelastic, an export supply elasticity estimate over 1.0 or even 0.5 seems equally unlikely given the nature of production controls. Nevertheless, we consider a range of alternative export supply elasticities from zero to two in our analysis to facilitate discussion of the possible extremes in the consequences of absolute to progressively less supply control and the implications for the Norwegian whitefish industry. In fact, we simulate five 
alternative levels of the whitefish price and export quantity effects of NSC whitefish promotion corresponding to five alternative Norwegian export supply elasticities: (1) 0 , (2) 0.5 , (3) 1.0 , (4) 1.5, and (5) 2.0. The elasticities at the lower end represent absolute supply control $(0)$ or at least reasonably effective supply control (0.5), while those at the upper end (1.5 and 2.0) represent the extreme limits of a failure to control supply effectively.

\section{Counterfactual (Simulation) Analysis Procedure}

To determine the effects of NSC promotion on Norwegian whitefish exports, two sets of scenarios were simulated with the model (equations [1] - [3]) using the econometric results for equation (1) from estimating the parameters for whitefish export demand: (1) a "with NSC export promotion" simulation (referred to as the "with" scenario) and (2) five "without NSC export promotion" simulations corresponding to the five alternative assumptions for the whitefish export supply elasticity in equation (2) of the model (referred to as the "without" scenarios). The use of simulation analysis in evaluations of the effectiveness of export promotion programs is standard practice in the literature (see Williams et al. 2016.)

The with scenario represents actual history, that is, the export volume, value, and price of Norwegian whitefish which include the effects of the NSC whitefish export promotion expenditures over time. The without scenario analyses were conducted by setting both the historic values of NSC export promotion expenditures in equation (1) and the export levy $(\theta)$ in equation (2) to zero and then simulating the model to determine the volume, price, and value of Norwegian whitefish exports for each of the five alternative export supply elasticities used in equation (2) of the model representing the absence of NSC promotion over time in each case.

Differences in the simulated levels of Norwegian whitefish export volume, value, and price in the five with scenarios from those in the without scenario are direct measures of the effects of the NSC whitefish export promotion program in each case. No exogenous variable in the model (e.g., levels of inflation, exchange rates, income levels) other than the NSC promotion expenditures are allowed to change in any of the five without scenarios.

\section{Benefit-Cost Calculation}

A common measure of the "benefit" used in benefit-cost analyses of export promotion programs is the additional export revenue generated given that the promotion objective is to increase export sales. The simulated additions to Norwegian whitefish export revenue induced by NSC whitefish export promotion (RX) can be calculated as:

$$
\mathrm{RX}_{\mathrm{jt}}=N \mathrm{NP}_{\mathrm{jt}}^{\mathrm{w}} \mathrm{NW} \mathrm{X}_{\mathrm{jt}}^{\mathrm{w}}-\mathrm{NWP}_{\mathrm{t}}^{\mathrm{wo}} \mathrm{NW} \mathrm{X}_{\mathrm{t}}^{\mathrm{wo}}
$$


where $\mathrm{j}$ represents alternative export supply elasticities and $\mathrm{t}$ refers to a particular year. Both the export prices (NWP) and quantities (NWX) in Equation (4) include the supply-shifting, excise-tax-like effects of the levy ( $\theta$ ) paid in part by Norwegian whitefish exporters (see Figure 3).

The Gross Revenue BCR (GBCR) for each export supply curve elasticity (j) considered given the excise tax effect of the levy is then calculated as the total additional Norwegian export revenue generated over the period of promotion from equation (4) per NOK of exogenous promotion expenditures (E) over that period:

$$
\mathrm{GBCR}_{\mathrm{j}}=\sum_{\mathrm{t}=1}^{\mathrm{T}} \frac{\mathrm{RX}_{\mathrm{jt}}}{\mathrm{E}_{\mathrm{t}}}
$$

where T represents the last year of the promotion period. Note that E does not change as the supply elasticity changes in this ex-post analysis because we analyze the effects of a historically fixed and, therefore, exogenous level of promotion expenditures given different assumptions on the level of export supply responsiveness to price. ${ }^{5}$

Because NSC promotion represents a cost of generating additional whitefish export revenue, the expenditures to promote each whitefish type in each year must be netted out of the additional export revenue for the respective whitefish type to arrive at the net export revenue BCR:

$$
\mathrm{NBCR}_{j}=\sum_{\mathrm{t}=1}^{\mathrm{T}} \frac{\mathrm{RX}_{\mathrm{jt}}-\mathrm{E}_{\mathrm{t}}}{\mathrm{E}_{\mathrm{t}}} .
$$

Revenue-based BCRs are often the metric of interest among export promotion groups because revenue generation is typically an explicit goal of promotion. Even so, revenue-based export BCR measures may be misleading as promotion metrics because they fail to account for the additional costs required to generate the additional export revenue. To account for such costs, we can calculate the more appropriate change in export surplus (RS), as illustrated in Figure 3, to represent the "benefit" of promotion in year $t$ :

$$
\begin{aligned}
& \mathrm{RS}_{\mathrm{jt}}=\left(\mathrm{NWP}_{\mathrm{jt}}^{\mathrm{w}}-\mathrm{NWP}_{\mathrm{t}}^{\mathrm{wo}}\right) \mathrm{NWX}_{\mathrm{t}}^{\mathrm{wo}}+1 / 2\left(\mathrm{NWX}_{\mathrm{jt}}^{\mathrm{w}}-\mathrm{NWX}_{\mathrm{t}}^{\mathrm{wo}}\right)\left(N \mathrm{NP}_{\mathrm{jt}}^{\mathrm{w}}\right. \\
& \left.-N W P_{t}^{w o}\right) \text {. }
\end{aligned}
$$

The Net Export Surplus BCRs (SBCRs) are calculated by replacing $\mathrm{RX}_{\mathrm{jt}}$ with $\mathrm{RS}_{\mathrm{jt}}$ in equation (6). Although not precisely the same thing, export surplus,

\footnotetext{
5 A reviewer expressed concerns that tax shifting should lead to lower expenditures as the supply elasticity increases. If the analysis intended to determine the optimal expenditure level at different export supply elasticities rather than the effects of a historically exogenous level of expenditures on exports and prices at different supply elasticities, then the tax shifting that occurs as a result of the levy would indeed result in different expenditure levels as the export supply elasticity changes, as demonstrated by Kinnucan and Myrland (2000). See footnote 9.
} 
which approximates the Norwegian whitefish producer surplus, ${ }^{6}$ can be considered a measure of the Norwegian whitefish industry export profit. The concept of the export surplus as profit is particularly applicable to the Norwegian whitefish industry with restrictive fishery quotas because a higher price in this case primarily increases the profit of individual fishers.

In Kinnucan and Gong (2014), the change in producer surplus, a measure of the welfare effect associated with promotion, is approximated as a function of: (1) the own-price elasticity in the export market; (2) the export supply elasticity; (3) the export promotion elasticity; (4) the price elasticity of supply for domestic production; (5) the proportionate change in export price; (6) the proportionate change in export supply; and (7) the proportionate change in a "goodwill" stock variable in which the amount of advertising in the current period is a function of the current level of goodwill which in turn is a function of current and past advertising outlays. In our analysis, we explicitly account for all these variables in a structural model in which the parameters are econometrically estimated rather than assumed, except for the price elasticity of export supply. Consequently, our simulation analysis is tantamount, at least in theory, to that of Kinnucan and Gong (2014).

\section{Data}

Monthly data on Norwegian whitefish export volume and value were provided by NSC along with data on their monthly export promotion expenditures for 2003 to 2017 (NSC 2018). Monthly data for exchange rates, inflation rates (CPI), gross domestic products for importing countries were all obtained from the IMF (2018). The FAO aquaculture price index developed by Tveterås et al. (2012) was obtained from Tveterås (2018). The indicator variables were developed based on information provided by the NSC.

\section{Analysis of Supply Control and Norwegian Whitefish Export Demand Promotion}

We investigate the market effects and stakeholder benefits from NSC whitefish export demand promotion under alternative assumptions about the effectiveness of export supply control by first econometrically examining the effects of promotion on Norwegian whitefish export demand. We use those results in simulation analyses of the effects of supply control on the effectiveness of NSC whitefish export promotion programs. The results are subsequently used in a BCR analysis.

\footnotetext{
6 Recall that the domestic market accounts for only about 5 percent of the Norwegian whitefish catch, so that the export surplus approximates producer surplus in this case.
} 
Econometric Analysis of Whitefish Export Demand

For econometric estimation, equation (1) was operationalized as follows using monthly data from January 2003 through December 2017 (180 observations):

$\mathrm{NWXD}_{\mathrm{t}}=\mathrm{f}\left(\frac{\mathrm{NWPX}_{\mathrm{t}}}{\text { FAOPI }_{\mathrm{t}}} \mathrm{ER}_{\mathrm{t}}, \frac{\mathrm{NSPX}_{\mathrm{t}}}{\mathrm{FAOPI}_{\mathrm{t}}} \mathrm{ER}_{\mathrm{t}}, \frac{\mathrm{MGDP}_{\mathrm{t}}}{\mathrm{MCPI}_{\mathrm{t}}} \mathrm{ER}_{\mathrm{t}}, \mathrm{PDL}\left(\mathrm{G}_{\mathrm{t}-\mathrm{n}}\right), \mathrm{NWXD}_{\mathrm{t}-1} \mathrm{SEAS}_{\mathrm{t}}, \mathrm{I}_{\mathrm{t}}\right)$

where NWXD $=$ monthly Norwegian whitefish export volume; NWPX $=$ nominal price of Norwegian whitefish exports paid by importing countries; NSPX = nominal Norwegian salmon export price; FAOPI $=$ FAO aquaculture price index; $E R=$ trade-weighted index of the NOK exchange rates of the top 10 countries that import whitefish from Norway; $\mathrm{MGDP}=$ trade-weighted nominal GDP of those same countries; MCPI = trade-weighted consumer price index of those same countries; $\operatorname{PDL}\left(\mathrm{G}_{\mathrm{t}-\mathrm{n}}\right)=$ polynomial distributed lag model of the goodwill stock of Norwegian whitefish export promotion expenditures (G) over periods $t, \ldots t-n$, where $G_{t-n}=\left(\frac{E P_{t-n}}{M I_{t-n}} E R_{t-n}\right)$, EXP is the seasonally adjusted nominal NSC expenditures to promote whitefish exports, and $\mathrm{n}$ is the lag length determined as discussed previously; SEAS $=$ seasonal monthly indicator variables with December as the reference month; $I=i s$ a matrix of indicator variables for various events affecting Norwegian whitefish exports; and $\mathrm{t}=$ time period. Equation (8) was estimated in double log form using ordinary least squares.

Model selection criteria (AIC, SIC, and HQC) were used to determine the most appropriate equation specification. The selected equation explains 83.2 percent (adjusted R2) of the variation in Norwegian whitefish export demand (Table 1). The signs and magnitudes of all estimated coefficients are consistent with prior expectations. As well, the within-sample mean absolute percent error (MAPE) over the sample period is 6.3 percent. The goodness-of-fit and the MAPE characteristics indicate a high degree of reliability of the econometric analysis.

Despite the relatively large number of explanatory variables, to avoid the inadvertent omission of any other important quantitative or qualitative factors, the residuals were examined to determine if a systematic pattern existed by testing for the presence of serial correlation. The Breusch-Godfrey LM test was implemented due to the presence of a lagged dependent variable (Breusch 1978, Godfrey 1978). The null hypothesis of no serial correlation up to two lags was not rejected. This test is not only more general than the Durbin h-statistic but also more powerful statistically. In addition, ARCH tests, up to four lags of squared residuals, indicated the absence of any heteroscedasticity over time as well. The ARCH test regresses the squared residuals on lagged squared residuals and a constant. These tests further corroborate the appropriate specification of the model. 
Table 1. Econometric estimation results for Norwegian whitefish export demand $^{\mathrm{a}}$

\begin{tabular}{|c|c|c|c|c|}
\hline \multicolumn{5}{|c|}{ Dependent Variable: Natural Log of Norwegian Whitefish Exports (metric tons) } \\
\hline $\begin{array}{l}\text { Variables (in natural logs } \\
\text { except indicator variables) }\end{array}$ & $\begin{array}{l}\text { Parameter } \\
\text { Estimate }\end{array}$ & $\begin{array}{l}\text { Standard } \\
\text { Error }\end{array}$ & t Value & P-Value \\
\hline Intercept & 7.471931 & 0.763445 & 9.787124 & 0.0000 \\
\hline \multicolumn{5}{|l|}{ Seasonality } \\
\hline$@$ @EAS(1) & 0.160420 & 0.032389 & 4.952919 & 0.0000 \\
\hline @SEAS(2) & 0.255811 & 0.031261 & 8.183094 & 0.0000 \\
\hline @SEAS(3) & 0.302475 & 0.031745 & 9.528172 & 0.0000 \\
\hline @SEAS(4) & 0.100233 & 0.032316 & 3.101639 & 0.0023 \\
\hline @SEAS(5) & 0.087618 & 0.030903 & 2.835240 & 0.0052 \\
\hline$@ S E A S(6)$ & 0.021339 & 0.030865 & 0.691369 & 0.4904 \\
\hline @SEAS(7) & -0.007344 & 0.032587 & -0.225370 & 0.8220 \\
\hline @SEAS(8) & 0.020754 & 0.032382 & 0.640911 & 0.5225 \\
\hline$@ \operatorname{SEAS}(9)$ & 0.224433 & 0.031238 & 7.184625 & 0.0000 \\
\hline @SEAS(10) & 0.255365 & 0.031134 & 8.202194 & 0.0000 \\
\hline$@ \operatorname{SEAS}(11)$ & 0.131610 & 0.031933 & 4.121414 & 0.0001 \\
\hline \multicolumn{5}{|l|}{ Economic Factors } \\
\hline $\begin{array}{l}\text { Norwegian Whitefish Export Price/ } \\
\text { FAO aquaculture price index } \\
\text { (exchange-rate-adjusted) }\end{array}$ & -0.306969 & 0.055847 & -5.496602 & 0.0000 \\
\hline $\begin{array}{l}\text { Norwegian Salmon Export Price/ } \\
\text { FAO aquaculture price index } \\
\text { (exchange-rate-adjusted) }\end{array}$ & 0.111695 & 0.042007 & 2.658934 & 0.0087 \\
\hline $\begin{array}{l}\text { GDP of importing countries (real, } \\
\text { exchange-rate-adjusted) }\end{array}$ & 0.249274 & 0.062736 & 3.973388 & 0.0001 \\
\hline Inertia (lagged dependent variable) & 0.262777 & 0.059520 & 4.414970 & 0.0000 \\
\hline \multicolumn{5}{|l|}{ Qualitative Factors } \\
\hline Weather-Related Events & -0.148254 & 0.064220 & -2.308528 & 0.0223 \\
\hline Presence of Bigger Cod & 0.186070 & 0.047374 & 3.927663 & 0.0001 \\
\hline $\begin{array}{l}\text { Increases in Quota for Cod and } \\
\text { Haddock }\end{array}$ & 0.144482 & 0.065129 & 2.218413 & 0.0280 \\
\hline Financial Meltdown & -0.120507 & 0.062580 & -1.925635 & 0.0560 \\
\hline Recession & -0.258935 & 0.050199 & -5.158196 & 0.0000 \\
\hline \multicolumn{5}{|c|}{ Goodwill Variable of NSC Promotion Whitefish Expenditures } \\
\hline $\begin{array}{l}\text { NSC promotion expenditures in } \\
\text { current period }\end{array}$ & 0.02362 & 0.00634 & 3.727462 & 0.0003 \\
\hline
\end{tabular}


Table 1. Continued

Dependent Variable: Natural Log of Norwegian Whitefish Exports (metric tons)

\begin{tabular}{lcccc}
\hline $\begin{array}{l}\text { Variables (in natural logs } \\
\text { except indicator variables) }\end{array}$ & $\begin{array}{c}\text { Parameter } \\
\text { Estimate }\end{array}$ & $\begin{array}{c}\text { Standard } \\
\text { Error }\end{array}$ & t Value & P-Value \\
\hline $\begin{array}{l}\text { NSC promotion expenditures } \\
\quad \text { lagged one period }\end{array}$ & 0.03149 & 0.00845 & 3.727462 & 0.0003 \\
$\begin{array}{l}\text { NSC promotion expenditures } \\
\quad \text { lagged two periods }\end{array}$ & 0.02362 & 0.00634 & 3.727462 & 0.0003 \\
$\begin{array}{l}\text { Sum of Lags } \\
\text { Regression statistics: Adj. } \mathrm{R}^{2}=\end{array}$ & 0.07873 & 0.02112 & 3.727462 & 0.0003 \\
$\quad 0.8315 \mathrm{DW}=1.75$ & & & & \\
\hline
\end{tabular}

Source: Computations by the authors using the software package EVIEWS 9.5 (2018).

${ }^{a}$ All prices, GDP, and NSC whitefish promotion expenditures were exchange-rate adjusted. In addition, GDP and NSC expenditures were deflated by a trade weighted CPI representing the ten top importing countries.

The issue of price endogeneity was examined using a Wu-Hausman test by comparing instrument variable (IV) estimates (two-stage least squares (2SLS) estimates) to OLS estimates (Wu 1973, Hausman 1978). The hypothesis of the exogeneity of price was not rejected. ${ }^{7}$ Like most export demand promotion evaluation studies, promotion expenditures are predetermined in our model (see Williams et al. 2016). That is, the NSC determines the level of promotion expenditures based on decisions made by their board members. In turn, we explore the impact of these predetermined expenditure levels on the volume of Norwegian exports of whitefish.

The econometric results and associated statistics are provided in Table 1. The estimated whitefish export demand price elasticity of -0.31 is well within the range of those estimated by other whitefish demand studies. The estimated income elasticity of 0.25 is lower than reported by most of those studies except Hellandsjø (2015) for saithe.

Norwegian salmon and whitefish were found to be substitutes to some extent in importing countries (Table 1). While this finding is not new (see Singh, Dey, and Surathkal 2012 and 2014, Fousekis and Revell 2004), our estimated crossprice elasticity of 0.112 is comparatively low. Seasonality also was evident. Relative to December, Norwegian whitefish exports are highest in March (by 35.3 percent), February (by 29.2 percent), October (by 29.1 percent), September (by 25.2 percent), January (by 17.4 percent), November (by 14.1 percent), April (by 10.5 percent), and May (by 9.2 percent).

7 Econometric analyses in general principally rely on data that have unit roots. In this analysis, however, the continuous predetermined variables are stationary, based on the use of Augmented Dickey-Fuller (ADF) tests. 
Selected qualitative events were also found to be drivers of Norwegian whitefish exports. Attention to these influential events is warranted in any economic analysis (Belsley, Kuh, and Welsch, 1980). While economic variables like purchasing power in importing countries, the export price of whitefish, exchange rates, and other variables largely explain the longer-term trends in Norwegian whitefish export demand, such events account for much of the deviation of export demand around the trend from year to year. To determine what events have impacted exports across time, we sequentially tested the effects of numerous events identified in discussion with NSC officials as potentially having had an impact on aggregate Norwegian whitefish export demand in various years. Of those events, the following were found to be clearly statistically significant over the study period, as indicated in Table 1: (1) weather-related events, particularly in 2006 and 2015; (2) the presence of bigger cod beginning in 2010; (3) increases in quotas for cod (2011 and 2013) and haddock (2009 to 2011 and in 2016); (4) the global financial meltdown in 2007 and 2008; and (5) the recession in 2008 and 2009. Moreover, statistical evidence of rigidities or inertia in Norwegian whitefish exports was found. The estimated coefficient of the lagged dependent variable (0.26) indicates that Norwegian whitefish export demand tends to respond quickly to changes in market forces.

The results exhibited in Table 1 also provide evidence that NSC expenditures have had a positive and statistically significant impact on Norwegian whitefish export demand over the study period. In the analysis, we considered polynomial distributed lags of order 2 and order 3 with and without endpoint restrictions for lag lengths of order 1 through 12 . The specification that minimizes the model selection criteria consists of a second-degree polynomial with endpoint constraints together with a lag of two months. Thus, the impact of NSC export promotion is not felt all at once but instead is distributed over the current month of expenditure and the subsequent two months. Specifically, the econometric results indicate a short-run (contemporaneous) elasticity of NSC export promotion of 0.024 with a long-run (cumulative) elasticity of NSC export promotion of 0.079 . Both results are in accord with those reported for many U.S. export promotion programs (Reimer et al. 2017, Williams et al. 2016). The estimated long-run promotion elasticity is somewhat higher than reported for NSC salmon promotion which range from 0.0133 (Xie, Kinnucan, and Myrland 2009) to 0.059 (Myrland and Kinnucan 2000). Kaiser (2015) and Xie (2015) report NSC salmon promotion elasticities of 0.036 and 0.054 , respectively. ${ }^{8}$

\footnotetext{
8 A reviewer suggested that the econometric analysis also could consider whether promotion expenditures increased price in order to add to the confidence in the reliability of the empirical results. We recognize this point and plan to consider this issue in further research.
} 


\section{Simulation Analysis of NSC Whitefish Export Promotion}

The simulation analysis examines the implications of various levels of export supply control from absolute to essentially no control on the effectiveness of NSC promotion on Norwegian whitefish exports and on the profitability of the Norwegian whitefish industry over the study period using the econometric results of estimating equation (8) in the model. The implications of absolute supply control for NSC export promotion were represented by a without scenario in which the export supply elasticity was set to zero in the model. The effects of progressively less effective export supply control were represented in four additional simulations in which the export supply elasticity was set at successively higher levels, including: (1) 0.5, (2) 1.0, (3) 1.5 , and (4) 2.0 as discussed in the methodology section.

For each alternative export supply elasticity, the simulated differences in the levels of Norwegian whitefish export volume, price, value, and industry profit between the with and the respective without scenarios represent the additions to each as a direct result of investment by the Norwegian whitefish industry in the NSC promotion programs. Those differences are often referred to as the "lift" provided by a promotion program over the period of analysis. The "lift" achieved by a promotion program is the addition to total sales value or other industry measures as a result of the promotion, that is, how much higher sales or other industry measures were over time than they would have been if the promotion had not been conducted.

The results indicate that assuming absolute supply control (export supply elasticity of zero) over the 15-year period of the analysis, export promotion generates a substantial price lift of nearly 20 percent with no export volume response (Table 2). As the level of export control (unresponsiveness of the export supply to price) diminishes, the price lift also diminishes to as low as 2.3 percent for an export supply elasticity of 2.0 , while the lift to export volume increases to 4.6 percent. At the same time, as the level of export control diminishes, the lift to export revenue and industry profit also declines.

With absolute supply control over the 15 years of analysis, the export revenue and industry profit lifts from NSC whitefish export promotion would have reached a maximum of 16 percent and 32 percent, respectively, with no additions to actual sales of Norwegian whitefish (Table 2). With little or no supply control (export supply elasticity of 2.0), the export revenue lifts would have reached no more than 4.8 percent and 3.3 percent. Given the price inelasticity of the Norwegian export demand, the Norwegian whitefish industry maximizes the benefit from promotion when export supply control is most restrictive. These results may explain why Norwegian whitefish export prices and revenues tend to increase dramatically as supplies are constrained by quotas during the year. 
Table 2. Estimated lift ${ }^{\mathrm{a}}$ from NSC whitefish export promotion under alternative levels of export supply control (export supply elasticities), 2003-2017

\begin{tabular}{|c|c|c|c|c|c|}
\hline \multirow[b]{3}{*}{ Lift to: } & \multicolumn{5}{|c|}{ Alternative Levels of Export Supply Control ${ }^{b}$} \\
\hline & \multirow{2}{*}{$\begin{array}{c}\text { AbsoluteControl } \\
(0)\end{array}$} & \multirow{2}{*}{$\begin{array}{c}\text { HighControl } \\
(0.5)\end{array}$} & \multicolumn{3}{|c|}{ Progressively Less Effective Control } \\
\hline & & & $(1.0)$ & $(1.5)$ & $(2.0)$ \\
\hline \multicolumn{6}{|l|}{ Exports (mt) } \\
\hline - All Years & 0 & 114,508 & 212,016 & 231,902 & 243,146 \\
\hline - Average Monthly & 0 & 643 & 1,191 & 1,303 & 1,366 \\
\hline - Percent & 0 & 2.1 & 4.0 & 4.4 & 4.6 \\
\hline \multicolumn{6}{|c|}{ Export Revenue (NOK million) } \\
\hline - All Years & 25,237 & 11,155 & 8,952 & 8,035 & 7,529 \\
\hline - Average monthly & 141.8 & 62.7 & 50.3 & 45.1 & 42.3 \\
\hline - Percent & 16.1 & 7.1 & 5.7 & 5.1 & 4.8 \\
\hline \multicolumn{6}{|c|}{ Industry Profit (NOK million) } \\
\hline - All Years & 25,237 & 7,584 & 4,575 & 3,287 & 2,568 \\
\hline - Average monthly & 141.8 & 42.6 & 25.7 & 18.5 & 14.4 \\
\hline - Percent & 32.0 & 9.6 & 5.8 & 4.2 & 3.3 \\
\hline \multicolumn{6}{|c|}{ Export Price (NOK/kg) } \\
\hline - Average Monthly & 4.68 & 1.55 & 1.01 & 0.77 & 0.64 \\
\hline - Percent & 19.7 & 5.7 & 3.7 & 2.8 & 2.3 \\
\hline
\end{tabular}

Source: Computations by the authors.

${ }^{a}$ Addition to indicated measures from NSC promotion (from without promotion to with promotion).

${ }^{\mathrm{b}}$ Numbers in parentheses are the corresponding levels of export supply elasticities used in the simulations. 


\section{Benefit-Cost Analysis of NSC Whitefish Export Promotion}

Clearly, NSC export promotion has effectively boosted the price and revenues of Norwegian whitefish exports along with Norwegian whitefish industry profit regardless of the level of supply control. Perhaps more important to the industry is whether the export revenue and industry profit lifts induced by the promotion were substantial enough to more than cover their cost of financing the promotion. If not, then the promotion of whitefish should be discontinued because the promotion has cost stakeholders more than it has returned to them.

Because the level of benefits depends on the level of supply control, the returns per NOK spent on promotion also depends on the level of supply control. Based on equations (5) through (7'), the BCRs (GBCR, NBCR, and SBCR) for the NSC promotion of whitefish exports were calculated over the study period for all levels of export control (export supply elasticities) considered in the analysis. A BCR greater than 1.0 implies that the program has more than paid for itself. Otherwise, the program generates an economic loss because the benefit earned is less than the cost.

The GBCR and NBCR for the NSC whitefish export promotion program range from lows of 6.9 and 5.9, respectively, given little or no export control to 23.1 and 22.1, respectively, for absolute export supply control (Table 3). Thus, for every krone of NSC export promotion expenditure, the return to the Norwegian whitefish stakeholders in additional export revenue net of the promotion expenditures (NBCR) ranges between 5.9 and 22.1 kroner from little or no export control to absolute control, respectively. The corresponding SBCR, however, ranges from barely profitable (1.4) to highly profitable (22.1). ${ }^{9}$ The SBCR is necessarily smaller than the NBCR because additional

\footnotetext{
9 Kinnucan and Myrland (2000) elegantly show that in calculating the optimal advertising intensity (and, thus, the BCR) when advertising is funded by an ad valorem tax, as is the case for the NSC whitefish export promotion program, the supply elasticity does not appear in the optimality condition. Thus, the SBCR in this case is invariant to the supply elasticity when calculating the optimal levy and, thus, the optimal level of promotion expenditures. However, this is not an optimality analysis. The SBCR is invariant to the supply elasticity only if the amount spent for promotion changes proportionally to the change in producer surplus (which is approximated by the change in export surplus in this analysis) as the supply elasticity changes as occurs with an ad valorem tax when promotion expenditures are assumed to be endogenous (as required in the optimality conditions). In contrast, this analysis considers the effects of a historically fixed level of promotion expenditures given different assumptions on the level of export supply responsiveness to price. Thus, the expenditures do not change as the supply elasticity changes because the expenditure levels are fixed (exogenous) historically in the analysis. Kinnucan and Myrland (2000) ask what level the advertising levy (and, thus, advertising expenditures) should be to maximize producer surplus. In contrast, we ask what the producer surplus and corresponding SBCR were over a historical period given the advertising expenditures that actually occurred. The total gain in producer surplus over the period of analysis is lower (the numerator in the SBCR calculations) with higher supply elasticities as should be the case, but the actual expenditures over that same period of analysis
} 
Table 3. Benefit-cost ratios (BCRs) for NSC whitefish export promotion under alternative levels of supply control (export supply elasticities), 2003-2017

\begin{tabular}{|c|c|c|c|c|c|}
\hline & \multicolumn{5}{|c|}{ Alternative Levels of Export Supply Control ${ }^{a}$} \\
\hline & \multirow{2}{*}{$\begin{array}{l}\text { AbsoluteControl } \\
\text { (0) }\end{array}$} & \multirow{2}{*}{$\begin{array}{c}\text { HighControl } \\
\text { (0.5) }\end{array}$} & \multicolumn{3}{|c|}{$\begin{array}{l}\text { Progressively Less } \\
\text { Effective Control }\end{array}$} \\
\hline & & & (1.0) & (1.5) & (2.0) \\
\hline $\begin{array}{l}\text { Additional Export } \\
\text { Revenue } \\
\text { (NOK million) }\end{array}$ & 25,237 & 11,155 & 8,952 & 8,035 & 7,529 \\
\hline $\begin{array}{l}\text { Additional Industry Profit } \\
\text { (NOK million) }\end{array}$ & 25,237 & 7,584 & 4,575 & 3,287 & 2,568 \\
\hline $\begin{array}{l}\text { NSC Promotion } \\
\text { Expenditures } \\
\text { (NOK million) }\end{array}$ & 1,092 & 1,092 & 1,092 & 1,092 & 1,092 \\
\hline $\begin{array}{l}\text { Gross Export Revenue BCR } \\
\text { (GBCR)c }^{\mathbf{c}} \\
\text { (NOK added/NOK spent) }\end{array}$ & 23.1 & 10.2 & 8.2 & 7.4 & 6.9 \\
\hline $\begin{array}{l}\text { Net Export Revenue BCR } \\
\text { (NBCR) }^{\mathbf{c}} \\
\text { (NOK added/NOK spent) }\end{array}$ & 22.1 & 9.2 & 7.2 & 6.4 & 5.9 \\
\hline $\begin{array}{l}\text { Net Export Surplus } \\
\text { (Profit) BCR (SBCR) } \\
\text { (NOK added/NOK spent) }\end{array}$ & 22.1 & 5.9 & 3.2 & 2.0 & 1.4 \\
\hline
\end{tabular}

Source: Computations by the authors.

a Numbers in parentheses are the corresponding levels of export supply elasticities used in the simulations.

${ }^{\mathrm{b}}$ Because this ex-post analysis considers the effects of a historically fixed (exogenous) level of promotion expenditures given different assumptions on the level of export supply responsiveness to price, the expenditures do not change as the supply elasticity changes.

${ }^{c}$ Revenue-based export BCR measures may be misleading as promotion metrics because they fail to account for the additional costs required to generate the additional export revenue. The SBCR accounts for such costs and is, thus, the more appropriate promotion metric.

${ }^{d}$ The domestic market accounts for only about 5 percent of the Norwegian whitefish catch so that the export surplus approximates producer surplus in this case.

economic costs have been netted out of the additional export revenue. With no supply control, the NBCR and SBCR are equal, because without any lift in exports, there are no additional costs of exporting to subtract from the additional export revenue generated by the NSC promotion. The calculated NSC whitefish export promotion BCRs assuming less than absolute export

(the denominator in the BCR calculations) remains the same in each case. Thus, the SBCR is lower at successively higher supply elasticities. 
supply control are in line with those calculated for salmon by Xie (2008 and 2015), Kaiser (2015), and others who assume Norwegian salmon export supply elasticities of between 1.0 to 2.0. The results are also consistent with those found for cod and skrei by CAPIA AS (2016).

\section{Conclusions and Implications}

Generic commodity promotion programs, like that of the Norwegian Seafood Council for whitefish exports, are intended to benefit the producers who finance the programs by increasing demand and prices, and therefore, industry profit. Even for such programs that effectively shift out demand, the return to producer investments in the promotion can be affected by the nature of the supply response to the promotion. For most U.S. agricultural commodity promotion programs, the concern is that an aggressive supply response could limit the price-supporting effects of promotion and moderate effective long-term benefit to the industry. For Norwegian whitefish exports, however, the concern is that supply controls could largely nullify efforts to expand export volume no matter how well the promotion program is executed.

This study finds that controlling supply tends to maximize the returns to those who fund cooperative advertising schemes by enhancing the value rather than the volume of sales. For the Norwegian whitefish industry, the returns from their investment in export promotion through the Norwegian Seafood Council in terms of profit gains is nearly 16 times higher (22.1 to 1) with absolute export supply control than with little or no control (1.4 to 1). In the latter case, the return to the whitefish industry in terms of additional profit is only slightly greater than one, so that little is gained from investments in promotion.

Absolute control is not likely the case for Norwegian whitefish fisheries, however, for various reasons. The prevention of overfishing is less than perfect. The catch has been under the TAC in various years, allowing for more supply response to price in those years. In addition, the quota limits themselves may be price responsive to some extent. In any case, the Norwegian export supply is likely somewhat more price responsive than the domestic supply because exports can increase as the export price rises by drawing down the supply available to the small domestic market. Norway exports about 95 percent of its domestic catch of whitefish each year, so the flexibility of exports to expand when export prices increase is limited. Thus, while not completely determined exogenously, the Norwegian export supply of whitefish is still likely price inelastic to some extent.

Assuming some level of effective supply control, however, most of the benefit from NSC export promotion to the Norwegian whitefish industry arises from a higher price and export revenue which add to industry profit despite the small effect on export volume. If the Norwegian export supply elasticity is around 0.5, representing relatively effective Norwegian whitefish export supply control, then NSC promotion likely added about 7 percent and 10 percent to industry 
revenue and profit, respectively, with a nearly 6 percent higher price over the 2003 to 2017 period of analysis despite a gain in export volume of only 2 percent. The corresponding gains in Norwegian whitefish industry revenue and profit per krone of investment over the study period, therefore, were likely around 9.2 and 5.9, respectively, results that are generally consistent with the gains reported by studies of U.S. export promotion programs (Williams et al. 2016).

A failure to effectively control supply over the study period, however, would have considerably compromised the whitefish export promotion efforts of the Norwegian Seafood Council. The same whitefish export promotion program efforts would have boosted Norwegian whitefish export volume by up to about 5 percent but with a substantially smaller boost to the export price and industry profit of only 2 percent and 3 percent, respectively. The consequence would have been a substantially lower return in terms of profit to Norwegian whitefish exporters per NOK they invested in export promotion. Thus, failure to control the whitefish export supply imposes a potentially large opportunity cost on the Norwegian whitefish industry from export promotion.

\section{Acknowledgements}

We gratefully acknowledge funding for this project from the Norwegian Seafood Council as well as their assistance in understanding the Norwegian whitefish industry and in providing us access to their financial, export, and other data for this report. We are particularly grateful to Dr. Asbjørn Warvik Rørtveit, former Director of Market Insight and Dr. Ingrid Kristine Pettersen, Seafood Analyst, Market Insight, for their assistance as well as many others on the NSC Staff and Board who shared data and information with us. Franck Asche and Sigbjorn Tveterås provided useful insights and a review of existing whitefish demand analysis literature. We are also grateful to anonymous reviewers for their comments. Nevertheless, the authors are solely responsible for the content of this article. The findings and conclusions are those of the authors and do not necessarily represent the views of the Norwegian Seafood Council or of Texas A\&M University.

\section{Funding Statement}

This research was supported by the Norwegian Seafood Council.

\section{Conflicts of Interest}

There are no conflicts of interest to report. 


\section{References}

Andersen, T.B., K.H. Roll, and S. Tveterås. 2008. "The Price Responsiveness of Salmon Supply in the Short and Long Run." Marine Resource Economics 23(4): 425-438.

Arnason, R. 2004. "Optimal Feedback Controls: Comparative Evaluation of the Cod Fisheries in Denmark, Iceland, and Norway." American J. of Agricultural Economics 86(2): 531-542.

Asche, F. 2009. "Adjustment Cost and Supply Response in a Fishery: A Dynamic Revenue Function." Land Economics 85(1): 201-215.

Asche, F. and R. Hannesson. 2002. "Allocation of Fish between Markets and Product Forms." Marine Resource Economics 17(3): 225-238.

Asche, F., S.C. Kumbhakar, and R. Tveterås. 2007. "Testing Cost Versus Profit Functions." Applied Economics Letters 14(10): 715-718.

Asche, F., K.H. Roll, and T. Trollvik. 2009. "New Aquaculture Species - The Whitefish Market." Aquaculture Economics and Management 13(2): 76-93.

Asche, F., and D. Zhang. 2013. "Testing Structural Changes in the U.S. Whitefish Import Market: An Inverse Demand System Approach." Agricultural and Resource Economics Review 42(3): 453-470.

Asheim, L.J., R.E. Dahl, S.C. Kumbhakar, A. Ogelend, and R. Tveterås. 2011. "Are Prices or Biology Driving the Short-term Supply of Farmed Salmon?" Marine Resource Economics 26(4): 343-357.

Belsley, D.A., E. Kuh, and R.E. Welsch. 1980. Regression Diagnostics: Identifying Influential Data and Sources of Collinearity. New York: Wiley \& Sons.

Besson, M., I. J. M. de Boer, M. Vandeputte, J. A. M. van Arendonk, E. Quillet, H. Komen, and J. Aubin. 2017. "Effect of Production Controls on Economic and Environmental Values of Growth Rate and Feed Efficiency in Sea Cage Fish Farming." PLoS One 12(3): e0173131.

Breusch, T. S. 1978. "Testing for Autocorrelation in Dynamic Linear Models." Australian Economic Papers 17: 334-355.

Bronnmann, J. 2016. "The German Whitefish Market: An Application of the LA/AIDS Model Using Retail-Scanner-Data." Aquaculture Economics and Management 20(4): 330-341.

CAPIA AS. 2016. "Effect of Generic Marketing of 'Skrei' and 'Fresh Cod'.' Unpublished report to the Norwegian Seafood Council, Trømso, Norway, February 15. A copy of this material is on file with the authors.

Carman, H.F. and R.D. Green. 1993. "Commodity Supply Response to a Producer-financed Advertising Program: The California Avocado Industry." Agribusiness: An International Journal 9(6): 605-621.

Chang, H.-S. and H.W. Kinnucan. 1991. "Economic Effects of an Advertising Excise Tax." Agribusiness: An International Journal 7(2): 165-171.

Cojocaru, A., F. Asche, R.B. Pincinato, and H-M. Straume. 2019. "Where Are the Fish Landed? An Analysis of Landing Plants in Norway." Land Economics. 95(2): 246-257.

EVIEWS 9.5. 2018. IHS Global Inc. Available at: www.eviews.com.

Food and Agriculture Organization of the United Nations (FAO). 1995. "Code of conduct for responsible fisheries." Rome. Available at: http://www.fao.org/fishery/code/en.

—. 2018. "GLOBEFISH - Analysis and Information on World Fish Trade." Rome. Available at: http://www.fao.org/in-action/globefish/fishery-information/resource-detail/en/c/ 338601/.

Fousekis, P. and B.J. Revell. 2004. "Retail Fish Demand in Great Britain and its Fisheries Management Implications." Marine Resource Economics 19(4): 495-510.

Ghosh, S. and G.W. Williams. 2016. "Generic Advertising of U.S. Lamb." International Journal of Food and Agribusiness Marketing 28(4): 373-393.

Godfrey, L.G. 1978. "Testing Against Autoregressive and Moving Average Error Models when the Regressors Include Lagged Dependent Variables.” Econometrica 46:1293-1301. 
Gullestad, P., A. Aglen, Å. Bjordal, G. Blom, S. Johansen, J. Krog, O.A. Misund, and I. Røttingen. 2014. "Changing Attitudes 1970-2012: Evolution of the Norwegian Management Framework to Prevent Overfishing and to Secure Long-term Sustainability." ICES Journal of Marine Science 71(2): 173-182.

Guttormsen, A.G., and K.H. Roll. 2011. "Technical Efficiency in a Heterogeneous Fishery." Marine Resource Economics 26(4): 293-308.

Hausman, J.A. 1978. “Specification Tests in Econometrics.” Econometrica 46(6): 1251-1271.

HAVFISK. 2015. "Industry Handbook: The Whitefish Industry 2015." Available at: http:// www.havfisk.no/en/investor-relations/reports-and-presentations/industry-handbook-.

Hellandsjø, L.V. 2015. Demand Analysis of the Whitefish Market in the EU-Has Pangasius Taken Over Market Shares in the Whitefish Market? M.S. thesis, School of Business and Economics, The Arctic University of Norway (UiT).

Hersoug, B. 2015. "The Greening of Norwegian Salmon Production." Maritime Studies 14: 16-34.

International Monetary Fund (IMF). 2018. International Financial Statistics. Available at: http://data.imf.org/?sk=388DFA60-1D26-4ADE-B505-A05A558D9A42.

Kaiser, H.M. 2015. "Economic Analysis of Norwegian Seafood Council Salmon Export Promotion to the European Union." Unpublished report to Norwegian Seafood Council, Troms $\emptyset$, Norway. A copy of this material is on file with the authors.

Kinnucan, H.W., H. Chang, and M. Venkateswaran. 1993. "Generic Advertising Wearout." Review of Marketing and Agricultural Economics 61(3): 1-15.

Kinnucan, H. W. and L. Gong. 2014. "Goodwill and Export Promotion Dynamics." Journal of Agricultural and Applied Economics 46: 73-89.

Kinnucan, H.W. and Ø. Myrland. 2000. "Optimal Advertising Levies with Application to the Norway-EU Salmon Agreement." European Review of Agricultural Economics 27:39-57.

- 2001. "A Note on Measuring Returns to Nonprice Export Promotion." Agribusiness: An International Journal 17(3): 423-433.

_. 2002. "Relative Impact of the Norway-EU Salmon Agreement: A Midterm Assessment." Journal of Agricultural Economics 53(2): 195-219.

- 2003. "Free-Rider Effects of Generic Advertising: The Case of Salmon." Agribusiness: An International Journal 19(3): 315-324.

- 2006. "The Effectiveness of Antidumping Measures: Some Evidence for Farmed Atlantic Salmon." Journal of Agricultural Economics 57(3): 459-477.

Kinnucan, H.W., R.G. Nelson, and H. Xiao. 1995. "Cooperative Advertising Rent Dissipation." Marine Resource Economics 10: 373-384.

Lee, J.Y. and M.G. Brown. 1986. "Economic Effectiveness of Brand Advertising Programs for U.S. Orange Juice in the European Market: An Error Component Analysis," Journal of Agricultural Economics 37: 385-394.

Msangi, S., M. Kobayashi, M. Batka, S. Vannuccini, M. Dey, and J. Anderson. 2013. "Fish to 2030: Prospects for Fisheries and Aquaculture." World Bank Report (83177-GLB), 102. Available at: http://www.fao.org/3/i3640e/i3640e.pdf.

Myrland, Ø. and H.W. Kinnucan. 2000. "Effects of Generic Advertising on Consumers' Attitudes, Revealed Preferences, and At-Home Food Consumption of Salmon in Germany and France." In R.S. Johnston (ed.), Proceedings of the International Institute of Fisheries Economics and Trade. Corvallis: Oregon State University.

Nerlove, M and K.J. Arrow. 1962. "Optimal Advertising Policy under Dynamic Conditions." Economica 26(114): 129-142.

Nerlove, M. and F.V. Waugh. 1961. "Advertising Without Supply Control: Some Implications of a Study of the Advertising of Oranges." Journal of Farm Economics 43: 813-837.

Norwegian Seafood Council (NSC). 2018. Data and information provided by direct communication with NSC and/or online from "Market Insight: Statistics." Available at: http://en.seafood.no/market-insight/. 
Pascoe, S. and S. Mardle. 1999. Supply Response in Fisheries-The North Sea. Research Paper 143, Centre for the Economics and Management of Aquatic Resources, University of Portsmouth, UK. Available at: http://www.vliz.be/en/imis?module=ref\&refid $=72729$

Pitcher, T. J., D. Kalikoski, K. Short, D. Varkey, and G. Pramod. 2009. "An Evaluation of Progress in Implementing Ecosystem-Based Management of Fisheries in 33 Countries." Marine Policy 33: 223-232.

Reimer, J., G.W. Williams, R. Dudensing, and H. Kaiser. 2017. "Agricultural Export Promotion Programs Create Positive Economic Impacts." Choices 32(3): 1-7.

Rudders, D.B. and J.M. Ward. 2015. “Own-Price Elasticity of Open Access Supply as a Long-run Measure of Fish Stock Abundance.” Marine Policy 53: 215-226.

Salvanes, K.G. and D. Squires. 1995. "Transferable Quotas, Enforcement Costs and Typical Firms: An Empirical Application to the Norwegian Trawler Fleet." Environmental and Resource Economics 6(1): 1-21.

Singh, K., M.M. Dey, and P. Surathkal. 2012. "Analysis of a Demand System for Unbreaded Frozen Seafood in the United States Using Store-Level Scanner Data." Marine Resource Economics 27(4): 371-387.

- 2014. "Seasonal and Spatial Variations in Demand for and Elasticities of Fish Products in the United States: An Analysis Based on Market-level Scanner Data." Canadian Journal of Agricultural Economics 62(3): 343-363.

Statista. 2018. "Average Export Price of Frozen Whole Cod from Norway from 2008 to 2017." Available at: https://www.statista.com/statistics/666081/average-export-price-offrozen-whole-cod-from-norway/.

Steen, F., F. Asche, and K.G. Salvanes. 1997. "The Supply of Salmon in EU: A Norwegian Aggregated Supply Curve." SNF Working Paper 53/97. Norwegian School of Economics and Business, Bergen, Norway.

Tveterås, S. 2018. Professor in Industrial Economics, Department of Industrial Economics, University of Stavanger, Norway. Personal communication (February 19).

Tveterås, S., F. Asche, M.F. Bellemare, M.D. Smith, A.G. Guttormsen, A. Lem, K. Lien, and S. Vannuccini. 2012. "Fish is food - The FAO's Fish Price Index." PLoS ONE 7(5): e36731.

Ward, R. W. and B. L. Dixon. 1989. "Effectiveness of Fluid Milk Advertising Since the Dairy and Tobacco Adjustment Act of 1983." American J. of Agricultural Economics 76: 730-740.

Williams, G.W. and O. Capps Jr. 2017. "How Effectively Does the Norwegian Seafood Council Promote Norwegian Seafood Exports?" Report to the Norwegian Seafood Council, Forecasting and Business Analytics (FABA), College Station, Texas, June. Available at: https://seafood.azureedge.net/4a558c/globalassets/markedsinnsikt/bedriftsrapport/ how-effectively-does-the-norwegian-seafood-council-promote-seafood-exports-repo rt-june-2017.pdf.

Williams, G.W. and O. Capps Jr. 2018. "Generic Promotion of Sorghum for Food and Industrial Uses." International Journal of Food and Agribusiness Marketing. DOI: 10.1080/ 08974438.2018.1533510.

Williams, G.W., J.J. Reimer, R.M. Dudensing, B.A. McCarl, H.M. Kaiser, and J. Somers. 2016. "Economic Impact of USDA Export Market Development Programs." Informa Economics, IEG, Prepared for U.S. Wheat Associates, USA Poultry and Egg Export Council, Pear Bureau Northwest, and the USDA Foreign Agriculture Service, June. Available at: https://www.fas.usda.gov/sites/default/files/2016-10/2016econimpactsstudy.pdf

Williams, G.W., C.R. Shumway, and H.A. Love. 2002. "Returns to Soybean Producers from Investments in Promotion and Research." Agricultural and Resource Economics Review 31(1): 97-111.

$\mathrm{Wu}$, De-Min. 1973. "Alternative Tests of Independence between Stochastic Regressors and Disturbances." Econometrica 41(4): 733-750.

Xie, J. 2008. "Halo Effect of Norwegian Salmon Promotion on EU Salmon Demand." IIFET 2008 Vietnam Proceedings, University of Tromsø, Tromsø, Norway. Available at: https://pdfs. semanticscholar.org/f1c4/da33c0460c4cf272a093db61924d54d1cb48.pdf. 
2015. "Testing Advertising-Induced Rotation of Demand Curves in the EU Salmon Market." Aquaculture Economics and Management 19(2): 175-191.

Xie, J., H.W. Kinnucan, and Ø. Myrland. 2009. "Demand Elasticities for Farmed Salmon in World Trade." European Review of Agricultural Economics 36(3): 425-445.

Xie, J., and Ø. Myrland. 2010. "Modeling the Market Structure of the Spanish Salted Fish Market." Food Economics-Acta Agricult Scand C 7(2-4): 19-127. 